Schweiz. Z. Path. Bakt. 1946;9:665

\title{
Hintere Kantenabtrennung am Wirbelkörper.
}

\begin{tabular}{|l|l} 
H.v. & Meyenburg \\
\hline
\end{tabular}

Ausführliche Mitteilung mit Abbildungen erschienen in Radiologia Clinica,

Bd. XV, S. 210. 